\title{
FALSE POSITIVE REACTIONS IN TREPONEMAL TESTS*†
}

\author{
BY \\ ALFREDO J. JULIAN, JOSEPH PORTNOY, AND THE LATE HILFRED N. BOSSAK
}

Venereal Disease Research Laboratory, Venereal Disease Branch, Communicable Disease Center, Public Health Service, Atlanta 22, Georgia

Treponema pallidum antigens, for use in a variety of tests, are obtained from rabbits infected intratesticularly with virulent organisms. It is likely that the treponemes or extracts prepared from them are contaminated with rabbit tissue components. The influence of these tissue substances on the reactivity of prepared treponemal antigens, particularly in tests with human sera, has not been adequately studied.

This report describes the production of immobilizing antibodies against $T$. pallidum in goats injected with normal rabbit testicular homogenates. The relationship of these findings to the detection of treponemal antibodies in humans is discussed.

\section{Material and Methods}

Preparation of Normal Rabbit Testicular Homogenate

Testes were obtained aseptically from normal, TPI nonreactive rabbits, freed from fat, sliced, and homogenized in veronal buffer (U.S. Public Health Service, 1959), using a commercially available motorized homogenizer. The mixing bowl was surrounded by iced water. The final concentration of tissue in the homogenate was $0.2 \mathrm{~g}$ per $\mathrm{ml}$. Homogenates were either used fresh or stored at $-20^{\circ} \mathrm{C}$.

Frozen aliquots were thawed, homogenized in a Tenbroeck tissue homogenizer, and used for immunization. For agglutination tests and absorptions, the homogenates were centrifuged in the cold at $500 \mathrm{~g}$ for 15 min. Supernates were employed in agglutination tests.

For absorptions, $1 \mathrm{ml}$. aliquots of supernate were centrifuged in plastic tubes at $23,000 \mathrm{~g}$ for $20 \mathrm{~min}$. The supernate was discarded. For human sera, $1 \mathrm{ml}$. serum was added to the sedıment which was resuspended with a syringe and needle. Mixtures were incubated for one hour at $37^{\circ} \mathrm{C}$., then overnight in the refrigerator. Centri-

* Short paper read to World Forum on Syphilis and Other Treponematoses, Washington, D.C., September 4-8, 1962.

† Received for publication October 31, 1962. fugation was accomplished at $23,000 \mathrm{~g}$ for $20 \mathrm{~min}$. The supernate was filtered sterilely through a Millipore filter using a Swinny adapter. For animal sera, absorptions were carried out at room temperature using a mechanical rotator for $7 \mathrm{~min}$. After each rotational period the mixture was centrifuged at $23,000 \mathrm{~g}$ for $20 \mathrm{~min}$. and the supernate checked in the slide agglutination test. Further absorptions were accomplished until the reactivity in the slide test was abolished. Animals were bled regularly before and during the immunization period. Blood was generally collected one week after a given injection. The sera obtained were stored at $-15^{\circ} \mathrm{C}$. until tests were made.

\section{Immunization and Bleeding of Animals}

A young female goat, 4 months old, was injected intramuscularly in each hind leg with $5 \mathrm{ml}$. homogenate. This was repeated after one month. It was further injected three times a week for 2 weeks, followed by one week of rest. It was then injected twice a week for 2 weeks.

Two other female goats were immunized with $5 \mathrm{ml}$. homogenate in each leg twice weekly for 3 weeks.

Young hens of heavy breed, 6 to 9 months old, were injected intramuscularly into each leg with $2 \mathrm{ml}$. homogenate every month for 6 months.

Female rabbits from 10 to $12 \mathrm{lb}$. were injected subcutaneously with $3 \mathrm{ml}$. homogenate in each side of the trunk every month for 6 months.

Female guinea-pigs, 250 to $350 \mathrm{~g}$, were injected intramuscularly into each hind leg with $1.5 \mathrm{ml}$. homogenate every month for 6 months.

The Treponema pallidum immobilization (TPI) test (Nelson and Mayer, 1949) and the fluorescent treponemal antibody (FTA) test (Deacon, Freeman, and Harris, 1960) were performed as described in the "Manual of Serologic Tests for Syphilis" (U.S.P.H.S., 1959).

Tests for Agglutinating Antibodies using Normal Testicular Homogenates

Normal testicular homogenates were centrifuged at 30 
buffer to produce an optical density of 0.30 at $410 \mu$. This procedure yielded a more homogenous suspension with a range of particles similar in size to that generally obtained in preparing antigen for the TPI test.

The slide agglutination reaction was performed in a paraffin-ringed slide, using $.02 \mathrm{ml}$. adjusted testicular homogenate as antigen and $.02 \mathrm{ml}$. serum dilutions. Slides were rotated at 120 r.p.m. for $5 \mathrm{~min}$. and examined macroscopically for evidence of clumping.

Test for Agglutinating Antibodies using TPI Test Antigen Suspension

Equal amounts $(0.4 \mathrm{ml}$.) of serum and TPI test antigen, stored overnight, were mixed into test tubes and shaken at room temperature for $5 \mathrm{~min}$. on a mechanical shaker. Dark-field examinations were performed, using $.02 \mathrm{ml}$. of the mixture. The number of organisms per field and the clumping of the treponemes and testicular extract were noted.

\section{Results and Discussion}

Serological Response of Animals Immunized with Normal Testicular Homogenates (Table).

(a) Production of Immobilizing Antibodies.-In a previous study by Nielsen and Metzger (1959), no immobilizing antibody was demonstrated in sera obtained from rabbits immunized against a variety of bacteria and viruses. In the present study all three goats injected with normal testicular homogenates produced immobilizing antibodies as measured by the TPI test approximately 3 to 4 weeks after the first injection. Titres, expressed in terms of the highest dilution giving more than 50 per cent. immobilization, were relatively low, ranging from $1: 1$ to $1: 8$. However, one of the goats, after intensive immunization over a period of 4 months, attained a titre of $1: 64$. Absorption of the immune serum with normal testicular homogenates rendered it nonreactive. None of the chickens, rabbits, or guineapigs showed the presence of immobilizing antibodies when injected with the testicular homogenates.

TABLE

SEROLOGICAL REACTIVITY OF IMMUNIZED ANIMALS

\begin{tabular}{|c|c|c|c|c|c|}
\hline \multirow{2}{*}{\multicolumn{2}{|c|}{ Animal Species }} & \multirow{2}{*}{$\begin{array}{c}\text { Number } \\
\text { of } \\
\text { Animals }\end{array}$} & \multicolumn{3}{|c|}{$\begin{array}{l}\text { Presence }(+) \text { or Absence }(0) \text { of } \\
\text { Antibodies as Measured by: }\end{array}$} \\
\hline & & & $\begin{array}{l}\text { TPI } \\
\text { Test }\end{array}$ & $\underset{\substack{\text { Agglutina- } \\
\text { tion }}}{\text { NTH }}$ & 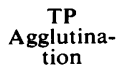 \\
\hline $\begin{array}{l}\text { Goat ... } \\
\text { Chicken } \\
\text { Rabbit.. } \\
\text { Guinea-Pig }\end{array}$ & $\begin{array}{l}. \\
\cdots \\
\cdots\end{array}$ & $\begin{array}{l}3 \\
6 \\
4 \\
6\end{array}$ & $\begin{array}{l}+ \\
0 \\
0 \\
0\end{array}$ & $\begin{array}{l}+ \\
+ \\
* \\
0\end{array}$ & $\begin{array}{c}+ \\
+ \\
\text { Not done } \\
\text { Not done }\end{array}$ \\
\hline
\end{tabular}

The failure to demonstrate immobilizing antibodies in the chicken antisera, which showed intense clumping of testicular homogenates and treponemes in the agglutination tests described below, was probably related to the general inability of certain avian sera to fix guinea-pig complement (Rice, 1947). It has been shown that immobilization of $T$. pallidum is a complement-dependent reaction (Nelson and Mayer, 1949). No attempt was made to detect immobilizing antibodies in an indirect complementfixation test (Rice, 1947).

(b) Production of Agglutinins.-The response of the experimental animals to the injection of normal testicular homogenates was also determined by the use of a slide agglutination technique, using the immunizing agent as test antigen. Clumping of the homogenate was obtained with immune goat and chicken sera. The reactions were most intense with chicken antiserum. Whereas pre-immune chicken and goat sera did not manifest agglutination, preimmune rabbit serum did so. The degree of agglutination of pre-immune and immune rabbit sera was the same. Immunized guinea-pigs did not show agglutinating antibodies.

The presence of apparent agglutinating antibodies against $T$. pallidum was noted with chicken and goat immune sera, using the suspension of organisms as obtained for the TPI test, but after overnight storage. The reactions were most intense with the chicken antisera and were characterized by large amorphous particles, presumably the tissue components, and clumps of treponemes which coincided with a reduction in the number of organisms per field. These reactions were abolished by absorption with normal testicular homogenates. Heating the antisera at $56^{\circ} \mathrm{C}$. likewise abolished the agglutinating characteristics.

Relationship of False Positive Reactions in the TPI Test with Goat Antisera to the Specificity of the TPI Test with Human Sera

The demonstration of immobilizing antibodies in goats immunized with normal testicular homogenates suggested that suspensions of treponemes as employed in the TPI test regularly contain adsorbed testes components and that the interaction of these components with suitable antibody and complement could produce immobilization. Human serum specimens from clinically documented cases obtained from a serum bank established at the Venereal Disease Research Laboratory for the purpose of evaluating serological tests were selected to determine whether immobilization reactions might in some instances be mediated by antigen-antibody 
interaction similar to that observed with goat antisera. Because of the increasing use of the FTA test (Deacon and others, 1960) and the similarity of the FTA antigen to that employed in the TPI test, it was considered appropriate to investigate this reaction as well. 23 specimens from patients diagnosed as biologic false positive on the basis of history but who gave reactive immobilization results were tested before and after absorption with normal testicular homogenates. No evidence of removal of antibody by such absorption was obtained. Similar treatment of several sera from patients with syphilis, yaws, and pinta likewise showed no change.

Repetition of this type of experiment, using ten specimens from hospital patients with a variety of diseases and in whom there was no clear-cut evidence of syphilis, likewise showed no effect, even after three cycles of absorption. In view of the demonstration by Muschel, Simonton, Wells, and Fife (1961) of complement-fixing tissue antibodies against rabbit liver homogenates in 74 per cent. of normal humans and the development of enhanced levels of these antibodies in patients with systemic lupus erythematosus and syphilis, the failure to demonstrate immobilization or fluorescence of $T$. pallidum mediated by testicular antigen and human antibody was somewhat surprising. On the other hand, the specificity of the TPI test would not be as high as has been reported (Zellmann and Lutz, 1956) if the tissue antibodies referred to by Muschel were operative in immobilization. The failure to obtain evidence of false positive reactions in treponemal tests in this study does not discount the possibility that such reactions might occur.
Summary

Immobilizing antibodies against Treponema pallidum were produced in goats immunized with normal rabbit testicular homogenates.

Absorption of human sera with normal rabbit testicular homogenates did not affect their reactivity in the TPI and FTA tests.

\section{REFERENCES}

Deacon, W. E., Freeman, E. M., and Harris, A. (1960). Proc. Soc. exp. Biol. (N.Y.), 103, 827.

Muschel, L. H., Simonton, L. A., Wells, P. A., and Fife, E. H., Jr. (1961). J. clin. Invest., 40, 517.

Nelson, R. A., Jr., and Mayer, M. M. (1949). J. exp. Med., 89, 369.

Nielsen, H. A., and Metzger, M. (1959). Brit. J. vener. Dis., 35, 241.

Rice, C. E. (1947). Canad. J. comp. Med., 11, 236.

U.S. Public Health Service (1959). "Manual of Serologic Tests for Syphilis". Public Health Service Publ. No. 411. U.S. Government Printing Office, Washington, D.C.

Zellmann, H. E., and Lutz, W. B. (1956). J. chron. Dis., 3, 390 .

Les réactions positives fausses aux tests d'immobilisation du tréponème

\section{RÉSUMÉ}

Ou produisit les anticorps immobilisant le $T$. pallidum dans des chèvres immunisées avec l'homogénat testiculaire du lapin normal. L'absorption du sérum humain avec cet homogénat n'eut aucun effet sur sa réactivité aux tests TPI et FTA. 